\title{
Frog vocalization is influenced by moon phases: Brazilian frogs tend to prefer low-albedo phases
}

\author{
Mauro S. C. S. Lima ${ }^{1}$, Jonas Pederassi ${ }^{2,3}$, Ulisses Caramaschi ${ }^{2}$, Kléssia Denise S. S. Sousa ${ }^{1}$, and \\ Carlos Alberto S. Souza ${ }^{4}$ \\ ${ }^{1}$ Departamento de Biologia, Universidade Federal do Piauí, Campus Amílcar Ferreira Sobral, BR 343, 3.5 km, \\ Bairro Meladão, 64800-000 Floriano, PI, Brazil \\ ${ }^{2}$ Departamento de Vertebrados, Museu Nacional, Universidade Federal do Rio de Janeiro, \\ Quinta da Boa Vista, São Cristóvão, 20940-040 Rio de Janeiro, RJ, Brazil \\ ${ }^{3}$ Associação Educacional Dom Bosco - AEDB, Av. Prof. Cel. Antônio Esteves, 1, \\ Campo de Aviação, 27523-000 Resende, RJ, Brazil \\ ${ }^{4}$ Laboratório de Ecologia, Conservação \& Mirmecologia, Programa de Pós-Graduação em Biologia Animal, \\ Instituto de Ciências Biológicas e Saúde, Universidade Federal Rural do Rio de Janeiro, \\ Campus Seropédica, BR 465, 7 km, 23890-000 Seropédica, RJ, Brazil
}

Correspondence: Jonas Pederassi (jonaspederassi@yahoo.com.br)

Received: 9 August 2020 - Revised: 17 October 2020 - Accepted: 2 November 2020 - Published: 6 January 2021

\begin{abstract}
Lunar phases remarkably influence the circadian cycle of living beings. Early amphibian studies date back to the 1960s, but only recently has more research been conducted in this field. Much still needs to be understood to establish the behavioral pattern of this group according to the synodic cycle. In the present study, we sought to determine (i) whether the vocalization activity was influenced by the lunar phases and (ii) whether the influence was species-specific or affects the community with equal intensity. We expected a great diversity of behaviors and adaptations. Rayleigh's test was used to verify whether the sample differs significantly from the null hypothesis; Rao's test was used to check sample size sufficiency; and the Kiviat diagram was used to evaluate the activity of the species in relation to the complete synodic cycle. We have observed 1691 individuals of 37 species over $882 \mathrm{~d}$. The lunar cycle influenced $78 \%$ of the species, with $32 \%$ preferring the lower-albedo phases. The activity pattern of each species was established. These results suggest that the lunar phases influence the vocalization activity of most species. Therefore, there is a general pattern of activity related to the synodic cycles; however, the specificities still need to be better understood.
\end{abstract}

\section{Introduction}

The relationship between species and environment and the species' biological or circadian cycle determine the behavior of populations and communities in an intricate association between endogenous and exogenous cycles, which directly influence the reproduction, foraging, dispersion, and migration periods of the species (Margalef, 1983; Zimecki, 2006). Biological cycles are believed to have concomitantly evolved with Earth's geological history and have since been refined by the selective pressures of the environment, increasing the fitness of the organisms (Paranjpe and Sharma, 2005).
Among the circadian cycles of animal activity, related to the photoperiod, we can highlight the lunar cycles (Neto, 1976). Animals in general present circadian cycles subject to environmental influence that leads to the release of neurohormones triggered by the electromagnetic radiation and the gravitational force of the moon. These forces may affect the reproductive cycle of complex organisms such as humans (Zimecki, 2006). The effects of the moon on vertebrates and changes in the vertebrates' behaviors have already been reported in fish (Oncorhynchus kisutch; Farbridge and Leatherland, 1987), birds (Bubo virginianus), and mammals (Vespertilionidae bats) (Parsons et al., 2003). In anurans, there are 
studies about the lunar influence from 1960 (Church, 1960a, b) through 2019 (Henrique and Grant, 2019). However, our knowledge remains incipient in this regard.

There are several theories on interrelations that could influence the activity of anuran amphibians regarding the lunar cycle (Grant et al., 2012), for example, the highest risk of predation during the full moon (Rand et al., 1997); reproductive synchronicity, mainly in explosive breeding species (Church, 1960a, 1961); the favoring of species that communicate with visual signals, in addition to bioacoustics (Sazima and Caramaschi, 1986; Hödl and Amézquita, 2001); facilitation in foraging; and spatial orientation (Longcore and Rich, 2004). Some of the older studies on lunar influence on anurans indicated that ovulation in many tropical species is directly linked to the lunar cycle (Church, 1960a, 1960b, 1961), whereas synchronism of vocalization of some species, such as Smilisca sila (Hylidae), and clarity of moonlight are related to the prey-predator condition (Tuttle and Ryan, 1982). Other studies have shown that luminosity is an important determinant in the reproduction of some anuran species: Engystomops pustulosus (Baugh and Ryan, 2010), Hyla intermedia, and Rana dalmatina (Vignoli and Luiselli, 2013). The movement of Leptodactylus latrans (Henrique and Grant, 2019) and its phenology (Grant et al., 2009) were influenced by the synodic cycle, which also influences the migration of Bufo bufo during spring and the species' reproductive period (Arnfield et al., 2012).

However, there is an agreement among these authors that the data have not yet shown sufficient robustness to establish the behavioral pattern of anurans with respect to the lunar cycle. Thus, in the present study, we seek to answer (i) whether the vocalization activity is influenced by the lunar phases and (ii) whether the influence is species-specific or affects the community with equal intensity. Hypothetically, due to the large diversity of anurans found in the neotropical region, similar behaviors and adaptations should be present; however, the expected patterns of influence of the synodic cycle on vocalization activity of most species should match the findings in the revision of Grant et al. (2012), where $63 \%$ of the species were influenced by the moon phases, $22 \%$ were unaffected, and $15 \%$ had ambiguous responses.

\section{Material and methods}

\subsection{Study area}

The data collection was performed in the hydrographic basins of the upper Rio Grande (in 20 localities encompassing the coordinates $22^{\circ} 9^{\prime} 24^{\prime \prime} \mathrm{S}, 44^{\circ} 33^{\prime} 13^{\prime \prime} \mathrm{W}$ to $22^{\circ} 9^{\prime} 59^{\prime \prime} \mathrm{S}$, $44^{\circ} 23^{\prime} 46^{\prime \prime} \mathrm{W}$ ) and upper Preto River (in 18 localities encompassing the coordinates $22^{\circ} 19^{\prime} 37^{\prime \prime} \mathrm{S}, 44^{\circ} 34^{\prime} 41^{\prime \prime} \mathrm{W}$ to $22^{\circ} 9^{\prime} 46^{\prime \prime} \mathrm{S}, 44^{\circ} 16^{\prime} 47^{\prime \prime} \mathrm{W}$ ) in the municipality of Bocaina de Minas $\left(22^{\circ} 09^{\prime} \mathrm{S}, 44^{\circ} 23^{\prime} \mathrm{W}\right)$, a south-southwest mesoregion of the state of Minas Gerais, comprising part of the Environmental Protection Area (APA) of Serra da Mantiqueira
(ICMBio, 2020). The location is in the eastern area of the southern region of the Mantiqueira Mountains (Gatto et al., 1983). The phytophysiognomy of the upper Preto River is dominated by the Atlantic ombrophilous dense forest and mixed ombrophilous forest merged with anthropic open pastures. The upper Rio Grande basin is dominated by mixed ombrophilous forest, montane forests at higher altitudes, and a large proportion of anthropic open pastures (Gatto et al., 1983). Inside these basins, all accessible reproductive environments were sampled (most of them flooded areas with ruderal vegetation, permanent ponds, rivers, streams, bromeliads, and leaf litter of the forests).

\subsection{Sample design}

The anuran sampling was performed through active visual and auditory search (Lima and Pederassi, 2015). Field observations were carried out, bi-monthly, between December 2014 and April 2017, in each of the hydrographic basins. In the sampling, the temporal pattern of the acoustic activity of each species was recorded to characterize a possible relationship with the lunar synodic cycle.

The sampling was conducted mainly at night between 18:00 and 01:00 BRT. Nevertheless, whenever a species was heard being active, that activity was added to the data. During sampling, the time pattern of vocalization of each species was monitored to characterize its possible relationship with the lunar synodic cycle. For those cases where the choruses were produced by an uncountable number of individuals, we set the maximum number of individuals to 20 for the analysis. This value represents only the minimum number of individuals in vocalization activity, and whenever used, indicates reproductive activity in choruses with countless individuals.

\subsection{Statistical and ecological analyses}

For uniformity and accuracy of the sampling period, calendar days were converted into Julian days, according to Costa (2000). Thus, the days were considered with intervals from noon to the next noon, disregarding time intervals of weeks, months, and years; thus, the sampling corresponded to 882 Julian days (JDs). The Julian day values were converted into degrees using the formula JD $\times 360 / 365$ (Costa, 2000) for use with statistical software.

\subsection{Circular statistics}

Records of vocalization activity associated with the lunar synodic cycle were analyzed by circular statistics (Batschelet, 1981; Jammalamadaka and SenGupta, 2001) using Oriana 4.02 software. The new moon was chosen as the azimuth zero, and the direction of angles was the modulus time. Thus, the full moon lies in the azimuth of $180^{\circ}$, the crescent moon is between 45 and $135^{\circ}$ with the first quarter at $90^{\circ}$, and the waning moon is between 225 and $315^{\circ}$ 

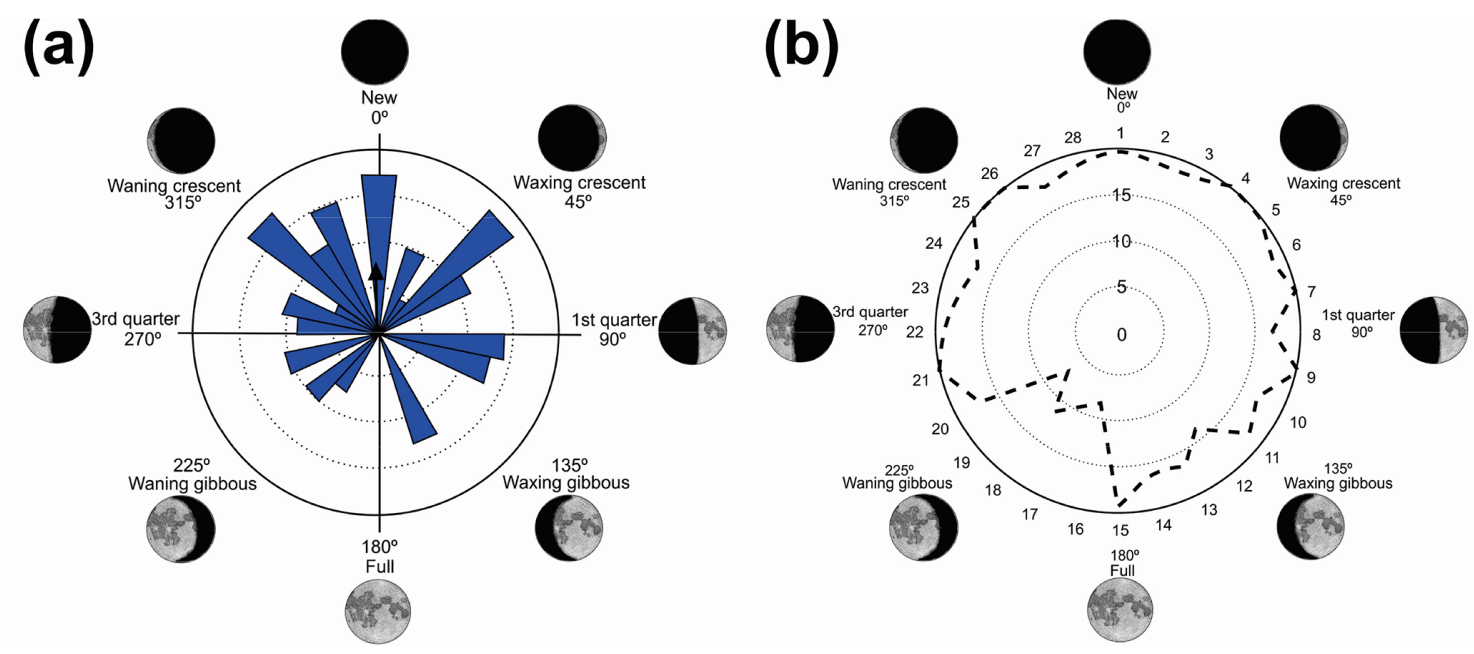

Figure 1. (a) Vocalization activity of the sample consisting of $N=1691$ individuals of 37 species and distribution of the respective synodic cycles throughout the sampling period. (b) Kiviat diagram in von Mises distribution revealing the relationship between the anuran activity and the lunar cycle. The dashed line represents the relative value of active specimens.

with the third quarter at $270^{\circ}$. To show the results, the quadrants were established in a way to maintain the new moon between 315 and $45^{\circ}$ in the first quadrant, the first quarter between 46 and $134^{\circ}$ in the second quadrant, the full moon between 135 and $225^{\circ}$ in the third quadrant, and the third quarter between 226 and $314^{\circ}$ in the fourth quadrant. The mean vector $(\mu)$ and its length $(r)$ were generated by the Oriana software through vectorial algebra. The mean vector $(\mu)$ establishes the mean location of the peak occurrence of the anuran species concerning the lunar influence, whereas the length of the mean vector $(r)$ was generated to determine the unidirectionality. In other words, the mean vector $(\mu)$ indicates the mean tendency of directedness and the length of the mean vector $(r)$ measures the angular dispersion. A zero (no length) means uniform dispersion, and 1 (total length) means absolute concentration in one direction (one-sidedness). If $r$ is sufficiently large, the null hypothesis can be rejected in favor of unidirectionality (Batschelet, 1981). Rayleigh's test $(Z)$ was applied to verify whether the sample differed significantly from the null hypothesis so that there is statistical evidence of unidirectionality, meaning that there is statistical evidence of directedness or one-sidedness as suggested by the generated mean vector (Batschelet, 1981). The value is considered unidirectional for $Z \geq Z(\alpha)$ and a standardized value of 6.62 , with $n-1$ degrees of freedom, $Z$ being the calculated value, and $Z(\alpha)$ being the standardized value. Rao's spacing test $(U)$ was used to verify sample size sufficiency and to determine the pairs (moon phase and anuran activity) that tend toward randomness, to allow the establishment of the unidirectionality between the anuran and moon variables. The value is considered random for $U<U(\alpha)$ and a standardized value of 164.8 , with $n-1$ degrees of freedom, $U$ being the calculated value, and $U(\alpha)$ being the standardized value. When there are insufficient data to meet the corollary of the test, the sample is considered insufficient (IS).

\subsection{Kiviat diagram}

The Kiviat diagram was used, through the von Mises distribution, to evaluate the performance of species with respect to the complete synodic cycle (Kolence and Kiviat, 1973), whose radial axis in a circumference represents the $29 \mathrm{~d}$ arranged on the maximum perimeter of the radial axis, ( $C=2 \pi r$, where $\pi=3.14$ and $r$ is the radius). The center of the circle is represented by zero percent, and successively, the frequencies of individuals per species are arranged for each sequential perimeter.

\section{Results}

We have recorded vocalization activity in 1691 individuals of 37 species belonging to the families Brachycephalidae (2 spp.), Bufonidae (1 sp.), Centrolenidae (2 spp.), Hylidae (20 spp.), Hylodidae (1 sp.), Leptodactylidae (6 spp.), Microhylidae (2 spp.), and Odontophrynidae (3 spp.). The vocalization activity of all 1691 individuals exhibited a unidirectional trend, forming an angle of $358^{\circ}$ (Fig. 1a). This corresponds to a trend in vocal activity during the moon phases of lower albedo (quadrant I). The sample size tests $(U=245.9)$ and absence of randomness $(Z=356.8)$ were significant with $p=0.01$ and $n-1$ degrees of freedom.

The results were validated by the Kiviat diagram through the von Mises distribution (Fig. 1b) for a synodic cycle of $29 \mathrm{~d}$, whose distribution presents the highest absolute frequency of species. Clockwise, the new moon is between the 1 st and the 7th day (maximum 20\%-minimum 17\%), the crescent moon is between the 8th and 15th day (maximum 
Table 1. Species with random vocalization activity throughout the moon cycle whose sample size was insufficient. RS = random sample; IS $=$ insufficient sample.

\begin{tabular}{|c|c|c|c|c|}
\hline $\begin{array}{l}\text { Species } \\
\text { (sample) }\end{array}$ & $\begin{array}{r}\text { Mean } \\
\text { vector }(\mu)\end{array}$ & $\begin{array}{r}\text { Length } \\
\text { of mean } \\
Z \text { vector }(r)\end{array}$ & $\begin{array}{r}Z \geq z(\alpha) \\
\text { tabulated } 6.62 \\
\text { Rayleigh's } \\
\text { test }(Z) 27.87\end{array}$ & $\begin{array}{r}U<U(\alpha) \\
\text { tabulated } 164.8 \\
\text { Rao's spacing } \\
\text { test }(U) 322.759\end{array}$ \\
\hline Aplastodiscus perviridis (6) & $140^{\circ}$ & 0.924 & $2.6^{\mathrm{RS}}$ & IS \\
\hline Dendropsophus microps (3) & $0^{\circ}$ & 1 & $1.0^{\mathrm{RS}}$ & IS \\
\hline Dendropsophus elegans (2) & $24^{\circ}$ & 0.309 & $0.2^{\mathrm{RS}}$ & IS \\
\hline Dendropsophus seniculus (5) & $288^{\circ}$ & 1 & $5.0^{\mathrm{RS}}$ & $288^{*}$ \\
\hline Elachistocleis cesarii (2) & $96^{\circ}$ & 1 & $3.0^{\mathrm{RS}}$ & IS \\
\hline Rhinella icterica (4) & $352^{\circ}$ & 1 & $4.0^{\mathrm{RS}}$ & IS \\
\hline Scinax sp. (1) & $156^{\circ}$ & 1 & $1.0^{\mathrm{RS}}$ & IS \\
\hline Vitreorana eurygnatha (2) & $0^{\circ}$ & 1 & $2.0^{\mathrm{RS}}$ & IS \\
\hline
\end{tabular}

* Sufficient sample.
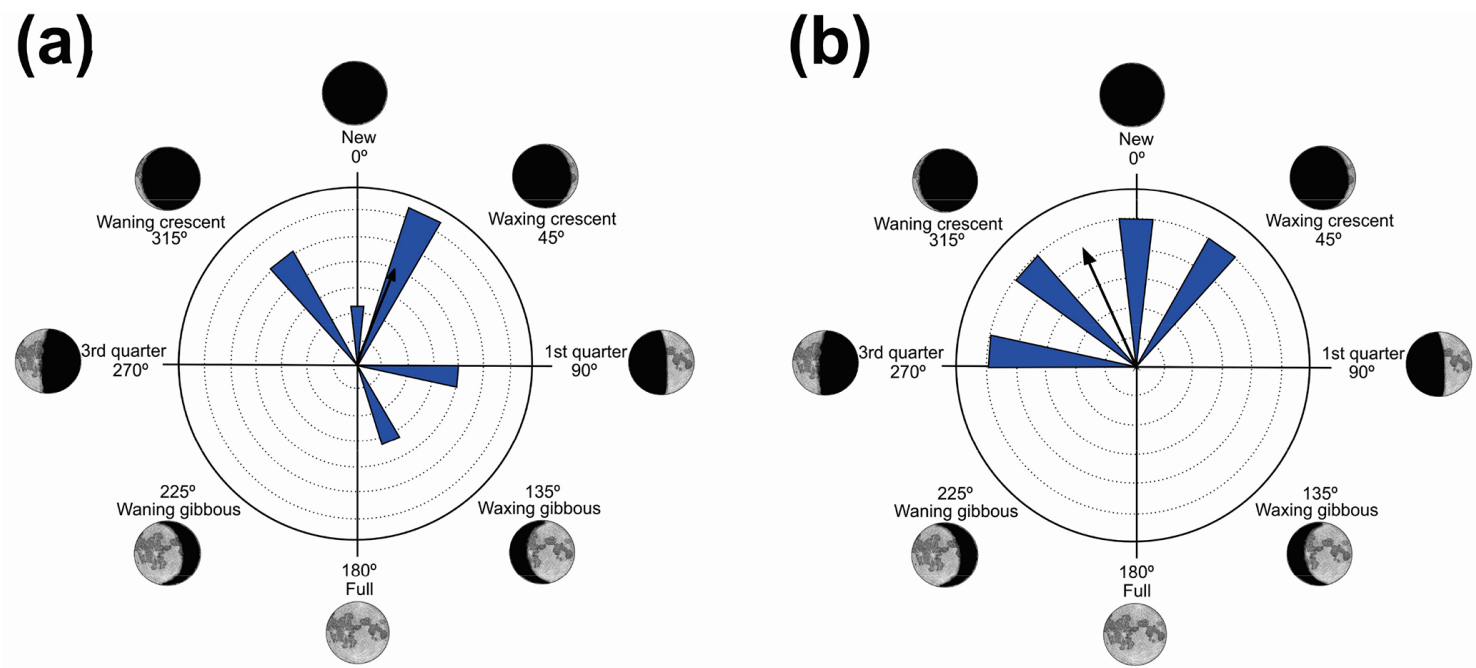

Figure 2. Species with sufficient sample size, characterized by randomness of behavior in the synodic cycle: (a) Leptodactylus jolyi and (b) Proceratophrys melanopogon.

$20 \%$-minimum $12 \%$ ), the full moon is between the 16th and 22nd day (maximum 16\%-minimum $7 \%$ ); and the waning moon is between the 23rd and 29th day (maximum $20 \%-$ minimum $17 \%$ ). Therefore, lunar phases of lower albedo were positively related to the activity of anuran species.

The 37 species were individually evaluated for the significant value of the sample, to test randomness $(Z)$ and unidirectionality $(U)$. In the eight species Aplastodiscus perviridis, Dendropsophus elegans, D. microps, Elachistocleis cesarii, Rhinella icterica, Scinax sp., and Vitreorana eurygnatha, the $Z$ test showed random behavior and the $U$ test showed insufficiency to determine unidirectionality. In the species Dendropsophus seniculus, the $Z$ test indicated randomness, whereas the $U$ test showed unidirectionality (Table 1).
Two species had sufficient sampling size and were considered to have random behavior (Table 2). Leptodactylus jolyi presented random behavior, and its activity vector $(r=58 \%)$ was aligned with the lunar cycle interval between the new moon and the first quarter at $21.9^{\circ}$ (Fig. 2a). Proceratophrys melanopogon presented random behavior, and its activity vector $(r=71 \%)$ was aligned with the lunar cycle interval between the third quarter and the new moon at $336^{\circ}$ (Fig. 2b).

The other species are distributed according to their mean vector $(\mu)$ of activity in the four quadrants that are presented below:

- Quadrant I. Twelve species presented a non-random unidirectional distribution in the polar axis between 315 and $45^{\circ}$ under the influence of the lunar synodic cycle from the waning crescent and waxing crescent (lower albedo) (Table 3, Fig. 3a-1). 

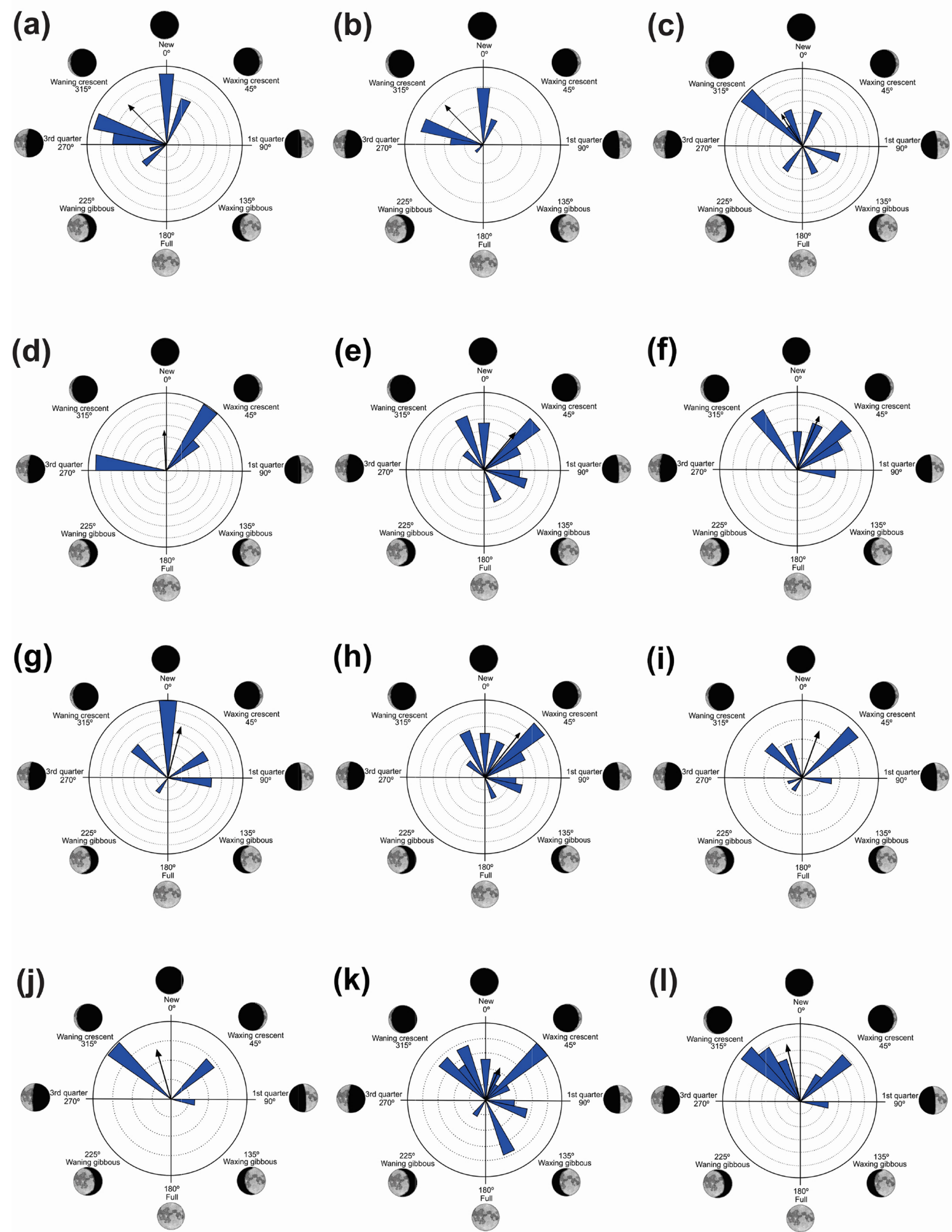

Figure 3. Species with unidirectional behavior in quadrant I of the polar axis (315-45 ) clockwise, under the influence of the synodic cycle between the waning crescent and waxing crescent (lower albedo): (a) Aplastodiscus albofrenatus, (b) A. arildae, (c) Dendropsophus minutus, (d) Ischnocnema parva, (e) Leptodactylus furnarius, (f) L. fuscus, (g) Odontophrynus americanus, (h) Physalaemus cuvieri, (i) S. duartei, (j) Scinax aff. hayii, (k) S. crospedospilus, and (l) Vitreorana uranoscopa. 
Table 2. Species with sufficient sample size and characterization of random behavior in the synodic cycle; $n-1$ degrees of freedom and $p=0.01$. RS $=$ random sample.

\begin{tabular}{|c|c|c|c|c|}
\hline $\begin{array}{l}\text { Species } \\
\text { (sample) }\end{array}$ & $\begin{array}{r}\text { Mean } \\
\text { vector }(\mu)\end{array}$ & $\begin{array}{r}\text { Length } \\
\text { of mean } \\
Z \text { vector }(r)\end{array}$ & $\begin{array}{r}Z \geq z(\alpha) \\
\text { tabulated } 6.62 \\
\text { Rayleigh's } \\
\text { test }(Z) 27.87\end{array}$ & $\begin{array}{r}U<U(\alpha) \\
\text { tabulated } 164.8 \\
\text { Rao's spacing } \\
\text { test }(U) 322.759\end{array}$ \\
\hline Leptodactylus jolyi (19) & $22^{\circ}$ & 0.58 & $6.4^{\mathrm{RS}}$ & $164.3^{\mathrm{RS}}$ \\
\hline Proceratophrys melanopogon (22) & $336^{\circ}$ & 0.71 & $2.0^{\mathrm{RS}}$ & $150.0^{\mathrm{RS}}$ \\
\hline
\end{tabular}

Table 3. Species with non-random unidirectional behavior in quadrant I of the polar axis $\left(315-45^{\circ}\right)$ clockwise, under the influence of the synodic cycle between the waning crescent and the waxing crescent (lower albedo); $n-1$ degrees of freedom and $p=0.01$.

\begin{tabular}{|c|c|c|c|c|}
\hline $\begin{array}{l}\text { Species } \\
\text { (sample) }\end{array}$ & $\begin{array}{r}\text { Mean } \\
\text { vector }(\mu)\end{array}$ & $\begin{array}{r}\text { Length } \\
\text { of mean } \\
Z \text { vector }(r)\end{array}$ & $\begin{array}{r}Z \geq z(\alpha) \\
\text { tabulated } 6.62 \\
\text { Rayleigh's } \\
\text { test }(Z) 27.87\end{array}$ & $\begin{array}{r}U<U(\alpha) \\
\text { tabulated } 164.8 \\
\text { Rao's spacing } \\
\text { test }(U) 322.759\end{array}$ \\
\hline Aplastodiscus albofrenatus (58) & $316^{\circ}$ & 0.69 & 27.9 & 322.8 \\
\hline Aplastodiscus arildae (129) & $318^{\circ}$ & 0.82 & 28.9 & 302.6 \\
\hline Dendropsophus minutus (43) & $326^{\circ}$ & 0.49 & 10.3 & 301.4 \\
\hline Ischnocnema parva (15) & $357^{\circ}$ & 0.51 & 3.9 & 300.0 \\
\hline Leptodactylus furnarius (95) & $41^{\circ}$ & 0.62 & 39.8 & 332.6 \\
\hline Leptodactylus fuscus (33) & $23^{\circ}$ & 0.74 & 19.2 & 298.3 \\
\hline Odontophrynus americanus (103) & $15^{\circ}$ & 0.66 & 54.0 & 345.4 \\
\hline Physalaemus cuvieri (62) & $38^{\circ}$ & 0.73 & 35.7 & 312,4 \\
\hline Scinax duartei (44) & $19^{\circ}$ & 0.61 & 16.4 & 310.9 \\
\hline Scinax aff. hayii (29) & $345^{\circ}$ & 0.64 & 13.3 & 326.3 \\
\hline Scinax crospedospilus (94) & $24^{\circ}$ & 0.44 & 27.8 & 330,0 \\
\hline Vitreorana uranoscopa (76) & $347^{\circ}$ & 0.72 & 44.7 & 334.9 \\
\hline
\end{tabular}

- Quadrant II. Seven species presented non-random unidirectional distribution in the polar axis between 46 and $134^{\circ}$ under the influence of the lunar synodic cycle from the waxing crescent and waxing gibbous (intermediate albedo) (Table 4, Fig. 4a-g).

- Quadrant III. Two species presented non-random unidirectional distribution in the polar axis between 135 and $225^{\circ}$ under the influence of the lunar synodic cycle from the waxing gibbous and waning gibbous (higher albedo) (Table 5, Fig. 5a-b).

- Quadrant IV. Six species presented non-random unidirectional distribution in the polar axis between 226 and $314^{\circ}$ under the influence of the lunar synodic cycle from the waning gibbous and waning crescent (intermediate albedo) (Table 6, Fig. 6a-f).

\section{Discussion}

The influence of changes in lunar phases on the behavior of fauna with nocturnal activity, although expected, is not well known, because the luminous intensity can vary by up to almost 2 orders of magnitude over a synodic cycle (Campbell et al., 2008; Grant et al., 2012). According to Church (1960a) and Grant et al. (2009), other measures of anuran reproductive behavior such as the amplexus and spawning are related to the lunar phase. In this study, we have not observed the amplexus or the spawning but the vocalization activity. The vocalization activity is closely associated with reproduction, being used as an indicator of the phenology of the species. Based on this premise and considering that anurans present synchronized reproductive periods, with rhythms between males and females and their vocalizations (Church, 1960a; Wells, 2007), we hypothesize that the phases of the moon influence this reproductive synchronism, markedly signaled by the vocalization activity (Wells, 2007). When evaluating the results, we identified that $32 \%$ of all species are under the influence of the cycle between the waning crescent $\left(315^{\circ}\right)$ and the waxing crescent $\left(45^{\circ}\right)$ (low-albedo phase) (Table 3 , Fig. 3).

Grant et al. (2009) when studying anurans in Europe (Italy and the United Kingdom) found divergent results since the full moon was the most influential moon phase, which corresponds to $180^{\circ}$ considering the azimuth established in the present study. Grant et al. (2009) worked in two specific reproductive cycles (2006 and 2007), and their sampling size 
Table 4. Species with non-random unidirectional behavior in quadrant II of the polar axis $\left(46-134^{\circ}\right)$ clockwise, under the influence of the synodic cycle between the waning crescent and waxing gibbous (intermediate albedo); $n-1$ degrees of freedom and $p=0.01$.

\begin{tabular}{|c|c|c|c|c|}
\hline $\begin{array}{l}\text { Species } \\
\text { (sample) }\end{array}$ & $\begin{array}{r}\text { Mean } \\
\text { vector }(\mu)\end{array}$ & $\begin{array}{r}\text { Length } \\
\text { of mean } \\
Z \text { vector }(r)\end{array}$ & $\begin{array}{r}Z \geq z(\alpha) \\
\text { tabulated } 6.62 \\
\text { Rayleigh's } \\
\text { test }(Z) 27.87\end{array}$ & $\begin{array}{r}U<U(\alpha) \\
\text { tabulated } 164.8 \\
\text { Rao's spacing } \\
\text { test }(U) 322.759\end{array}$ \\
\hline Boana albopunctata (137) & $52^{\circ}$ & 0.28 & 12.1 & 336.9 \\
\hline Boana pardalis (9) & $60^{\circ}$ & 0.91 & 7.4 & 280.0 \\
\hline Leptodactylus latrans (19) & $80^{\circ}$ & 0.76 & 11.0 & 272.2 \\
\hline Pseudopaludicola murundu (35) & $78^{\circ}$ & 0.95 & 36.2 & 342.0 \\
\hline Scinax similis $(8)$ & $48^{\circ}$ & 0.67 & 1.8 & 180.0 \\
\hline Scinax fuscomarginatus (41) & $72^{\circ}$ & 0.54 & 11.9 & 307.3 \\
\hline Scinax squalirostris (43) & $88^{\circ}$ & 0.65 & 20.0 & 330,0 \\
\hline
\end{tabular}

Table 5. Species with unidirectional behavior in quadrant III of the polar axis $\left(135-225^{\circ}\right)$ clockwise, under the influence of the synodic cycle between waxing gibbous and waning gibbous (higher albedo); $n-1$ degrees of freedom and $p=0.01$.

\begin{tabular}{|c|c|c|c|c|}
\hline $\begin{array}{l}\text { Species } \\
\text { (sample) }\end{array}$ & $\begin{array}{r}\text { Mean } \\
\text { vector }(\mu)\end{array}$ & $\begin{array}{r}\text { Length } \\
\text { of mean } \\
Z \text { vector }(r)\end{array}$ & $\begin{array}{r}Z \geq z(\alpha) \\
\text { tabulated } 6.62 \\
\text { Rayleigh's } \\
\text { test }(Z) 27.87\end{array}$ & $\begin{array}{r}U<U(\alpha) \\
\text { tabulated } 164.8 \\
\text { Rao's spacing } \\
\text { test }(U) 322.759\end{array}$ \\
\hline Boana faber (78) & $135^{\circ}$ & 0.10 & 18.5 & 313.8 \\
\hline Dendropsophus sanborni (63) & $138^{\circ}$ & 0.47 & 16.4 & 335.3 \\
\hline
\end{tabular}

included 130 specimens. In the present study, the sampling period was $882 \mathrm{~d}$ occurring between 2014 and 2017, and the sampling size is $N=1691$ specimens from 37 species, which is sufficient to characterize different results.

Nevertheless, in the present work, two species (B. faber and $D$. sanborni) had non-random unidirectional activity in the phase of higher albedo (135 and $225^{\circ}$ - Table 5, Fig. 5), although they showed vocal activity in the loweralbedo phase as well. Six species (D. minutus, L. furnarius, $O$. americanus, $P$. cuvieri, S. crospedospilus, and S. duar$t e i$ ) with preferential activity in lower-albedo phase (315 to $45^{\circ}$ - Table 3, Fig. 3) also showed activity between 135 and $225^{\circ}$ (higher albedo). Different strategies were expected considering the richness in local species. With the distinct evolutive history of the species, it was expected for a wide variety of behaviors, concerning moon phases, to have evolved with some species that are exclusively active in specific moon phases; others who concentrate their activity in a specific moon phase but are active in other phases as well; and, finally, some species that exhibit random activity, independently of the moon phase.

Vignoli and Luiselli (2013) found results similar to ours in Italy, regarding the predominance of activity in a period of lower albedo, and they characterized the behavior of the species as a lunar phobia. When analyzing the Kiviat diagram (Fig. 1b) the species of Serra da Mantiqueira could also receive this classification. According to Fig. 1b, although we can see a peak of activity during the full moon $\left(180^{\circ}\right)$, the species' activity remains at a higher level more constantly during the darkest phases $\left(270-90^{\circ}\right)$, and this is related to the greater number of species that take turns in vocal activity during the phases of lower albedo. This reveals a nonrandom pattern of anuran behavior (Bourne and York, 2001). These results validate the hypothesis that most species are influenced by the lunar phases.

The activity during the full moon in a higher-albedo phase may be related to visual behaviors and court displays (Duellman and Trueb, 1994). Guimarães and Bastos (2003), for example, observed that Boana raniceps (Cope, 1862), which is not negatively influenced by clear nights of a full moon, presents visual displays of aggressive behaviors common among males. The activity may also be related to the regulation of ovulation by lunar phases. Church (1960a) reported that in the Asian bufonid Duttaphrynus melanostictus (Schneider, 1799), ovulation occurred during or temporally near the full moon. Activity in the higher-albedo phase could be related to the greater ease of detecting the approximation of predators as reported by Tuttle and Ryan (1982) and Tuttle et al. (1982). Although we have not observed the influence of cloudy weather, Vignoli and Luiselli (2013) reported no influence of these abiotic data on the lunar-mediated anurans' behavior.

Considering the results found and that different hemispheres present similar results regarding the lunar cycle (Grant et al., 2009; Vignoli and Luiselli, 2013), including lunar phobia, the first hypothesis of the influence of the 

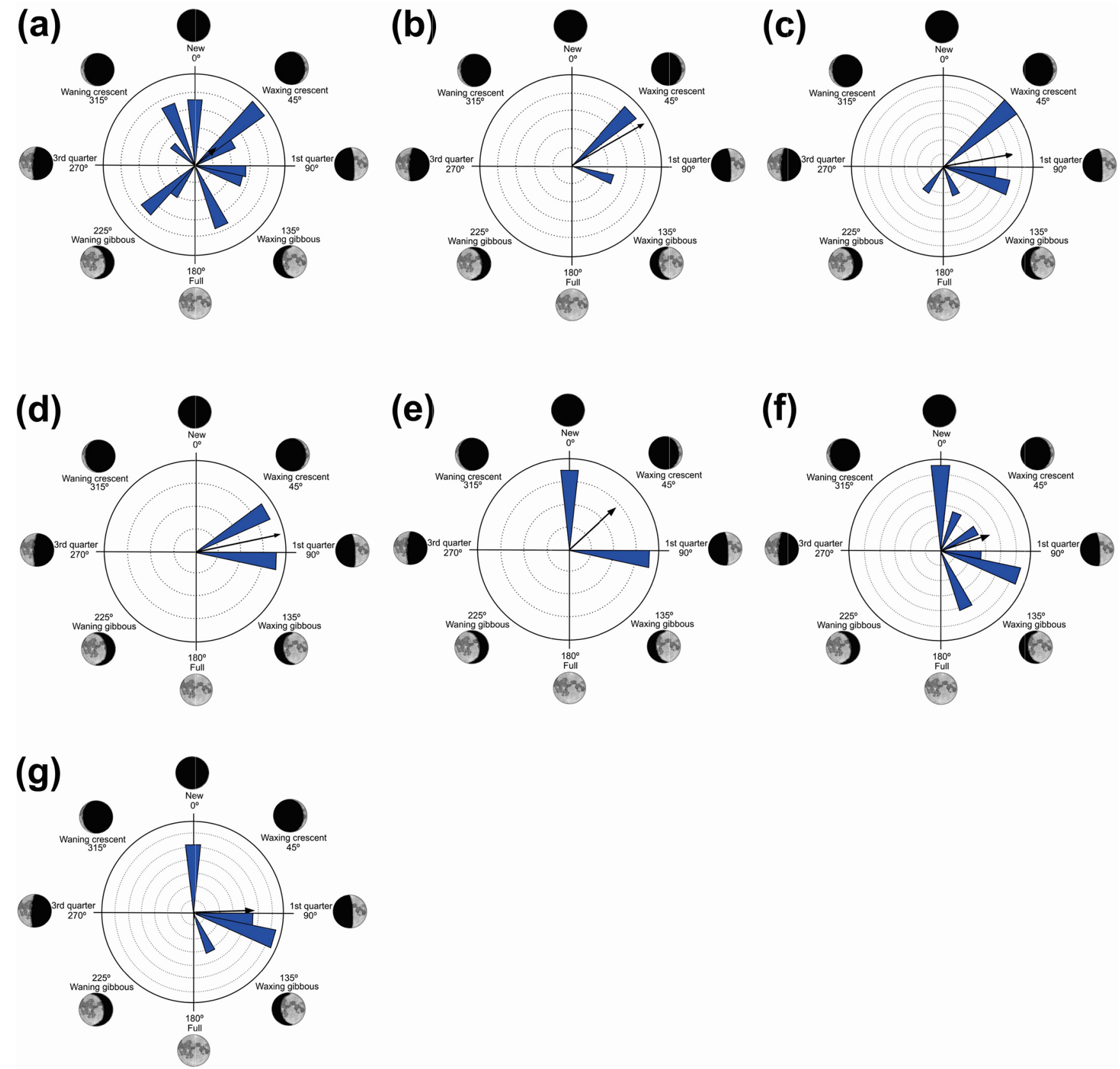

Figure 4. Species with unidirectional behavior in quadrant II of the polar axis (46-134 $)$ clockwise, under the influence of the synodic cycle between the waning crescent and waxing gibbous (intermediate albedo): (a) Boana albopunctata, (b) B. pardalis, (c) Leptodactylus latrans, (d) Pseudopaludicola murundu, (e) S. similis, (f) S. fuscomarginatus, and (g) S. squalirostris.

lunar cycle during the reproductive period of anurans at Bocaina de Minas can be validated, although further studies are necessary to explain the behavior of each species. Grant et al. (2012) made an extensive revision concerning the lunar-mediated behavior of amphibian species. They analyzed predator avoidance, reproductive synchronization, visual signaling, foraging, navigation, orientation, and homing. Although lunar phobia is better explained by predator avoidance (Clarke, 1983), the anurans' behavior is species- specific and varies according to their ecology and evolutive history (Tuttle et al., 1982; Tuttle and Ryan, 1982; Rand et al., 1997; Grant et al., 2012) and according to the predator's strategies to find prey, since most of the predators are not visually oriented (Tuttle et al., 1982; Vincent et al., 2005). This highlights that more research focusing specifically on this point is necessary to elucidate the ecological aspects of lunar-mediated behavior in anurans. 

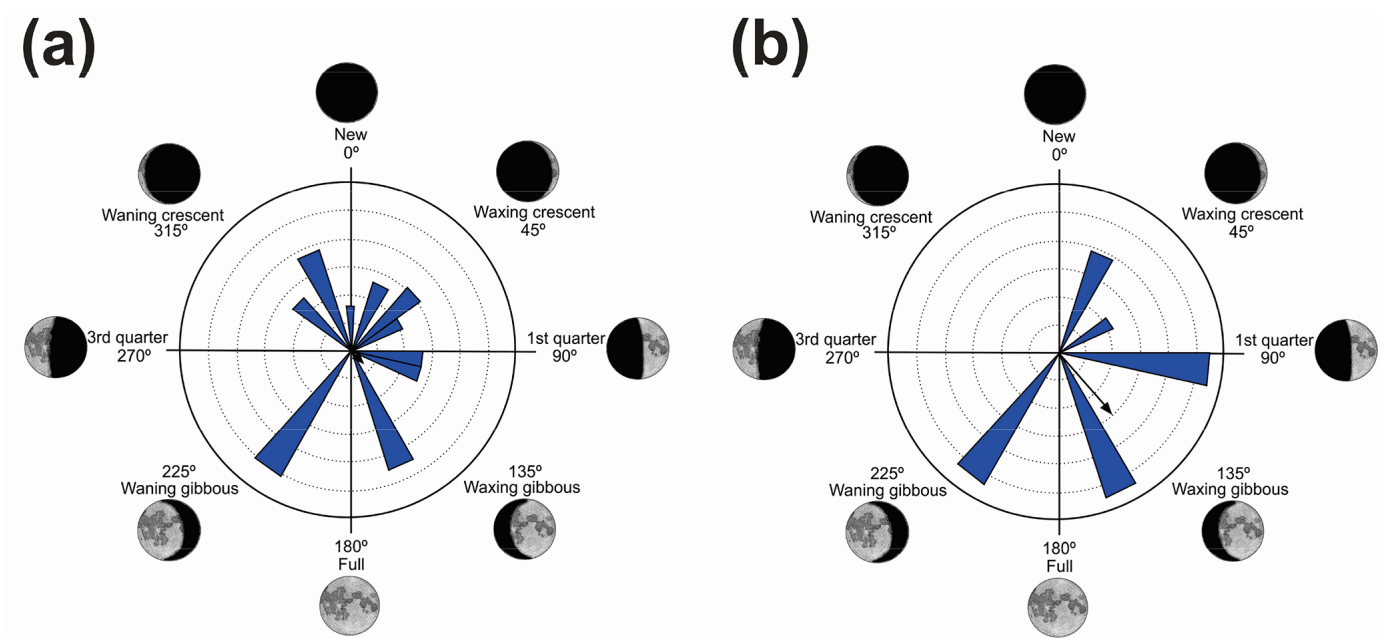

Figure 5. Species with non-random unidirectional behavior in quadrant III of the polar axis $\left(135-225^{\circ}\right)$ clockwise, under the influence of the synodic cycle between the waxing gibbous and waning gibbous (higher albedo): (a) Boana faber and (b) Dendropsophus sanborni.

Table 6. Species with non-random unidirectional behavior in quadrant IV of the polar axis $\left(226-314^{\circ}\right)$ clockwise, under the influence of the synodic cycle between the waning gibbous and waning crescent (intermediate albedo); $n-1$ degrees of freedom and $p=0.01$.

\begin{tabular}{|c|c|c|c|c|}
\hline $\begin{array}{l}\text { Species } \\
\text { (sample) }\end{array}$ & $\begin{array}{r}\text { Mean } \\
\text { vector }(\mu)\end{array}$ & $\begin{array}{r}\text { Length } \\
\text { of mean } \\
Z \text { vector }(r)\end{array}$ & $\begin{array}{r}Z \geq z(\alpha) \\
\text { tabulated } 6.62 \\
\text { Rayleigh's } \\
\text { test }(Z) 27.87\end{array}$ & $\begin{array}{r}U<U(\alpha) \\
\text { tabulated } 164.8 \\
\text { Rao's spacing } \\
\text { test }(U) 322.759\end{array}$ \\
\hline Boana polytaenia $(148)$ & $309^{\circ}$ & 0.29 & 14.4 & 333.6 \\
\hline Hylodes phyllodes (42) & $307^{\circ}$ & 0.56 & 13.3 & 317.1 \\
\hline Ischnocnema aff. guentheri (55) & $314^{\circ}$ & 0.69 & 31.1 & 315.7 \\
\hline Myersiela microps (43) & $285^{\circ}$ & 0.92 & 39.5 & 337.0 \\
\hline Ololygon hiemalis (41) & $253^{\circ}$ & 0.99 & 34.1 & 329.1 \\
\hline Proceratophrys boiei (82) & $303^{\circ}$ & 0.87 & 75.9 & 342.0 \\
\hline
\end{tabular}

Insufficient sampling was characterized by the rare nature of the activity of some species in the region during the sampling period. The rarity of $E$. cesarii and $R$. icterica vocalization activity was owing to these species' explosive reproduction behaviors (sensu Wells, 1977). Bastos et al. (2003) observed explosive reproduction in species of the genus Rhinella in the state of Goiás. Dendropsophus seniculus presents opportunistic reproduction after heavy rains (Bertoluci, 1998), which seems to justify its random pattern ( $Z$ test), although its sampling is sufficient ( $U$ test) (Table 1 ); i.e., the species' reproductive activity could be influenced by the volume of rain regardless of the lunar phase.

Although L. jolyi and P. melanopogon have a prevalence of vocalization activity during the darkest lunar phase (mean vector between 315 and $45^{\circ}$ - Fig. 2), this behavior was considered statistically random ( $Z$ and $U$ tests - Table 2). Leptodactylus jolyi vocalizes from the ground, in dry and high places, among the herbaceous vegetation of open areas (Eterovick and Sazima, 2004), whereas the activity of P. melanopogon is on the ground of forested swamps (Heyer et al., 1990). In the present study, P. melanopogon exhibited explosive reproduction in January, April, August, and December, always in the darkest phases, whereas L. jolyi exhibited prolonged reproduction (sensu Wells, 1977) from October to February, with activity also occurring in clearer phases $\left(135\right.$ to $\left.225^{\circ}\right)$, even if less frequently. These data suggest that the habitat does not interact with the influence of lunar phases on the species vocalization activities because the forest habitat, in the case of $P$. melanopogon, could, owing to shading of the canopy, negate the effect of the phases of the greater moon luminosity.

In the first quadrant $\left(315-45^{\circ}\right.$, lower-albedo phase) 12 species exhibited non-random unidirectional behavior (Table 3, Fig. 3). These species were observed vocalizing from open areas on the ground (L.furnarius, L. fuscus, O. americanus, and $P$. cuvieri, , perched on bushes or ruderal vegetation (D. minutus, S. crospedospilus, $S$. duartei, and $S$. aff. hayii), from leaf litter of forested areas (I. parva), or perched in the arbustive vegetation of rivulets in forested areas (A. albofrenatus, A. arildae, and $V$. uranoscopa). All of these pre- 

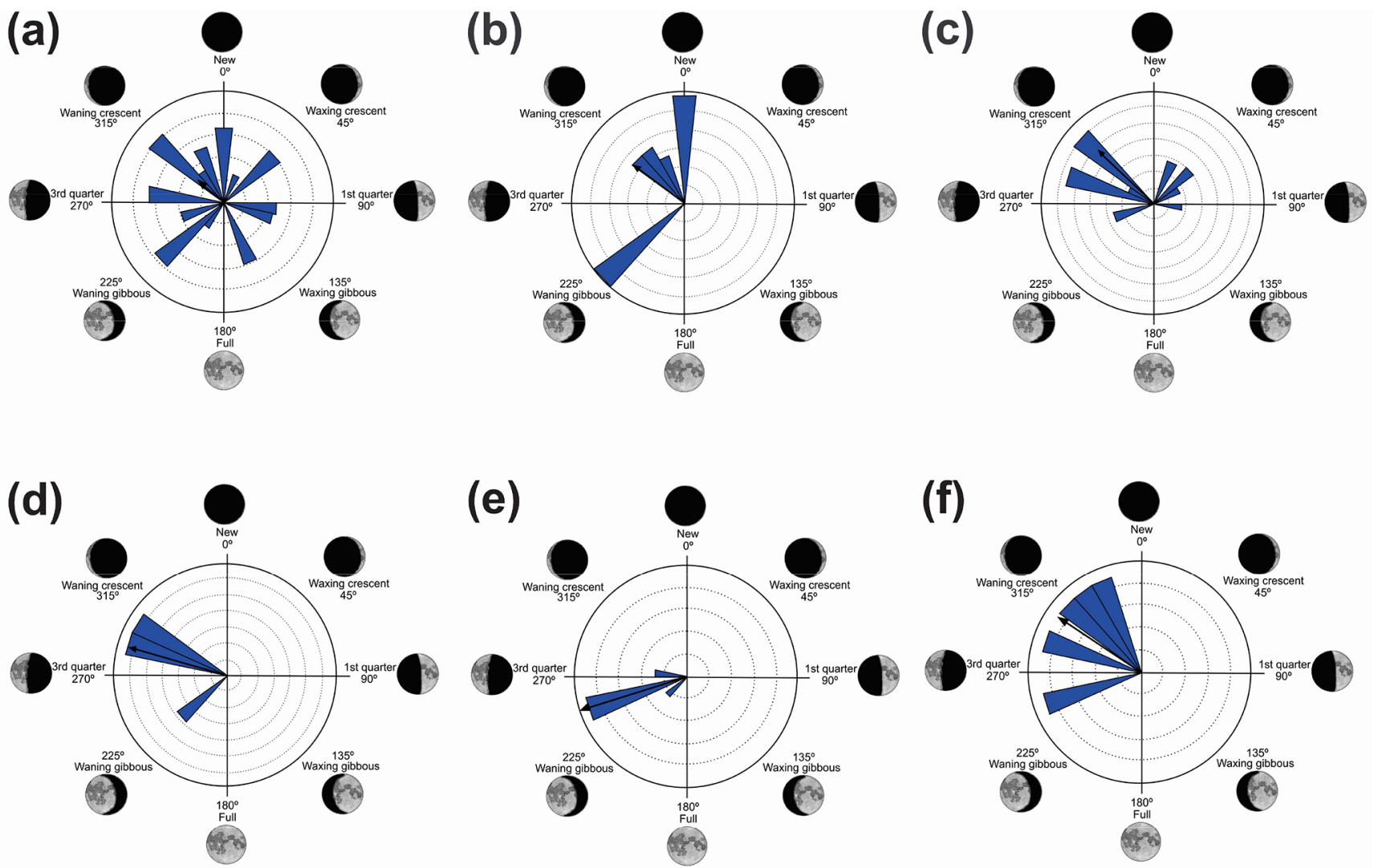

Figure 6. Species with non-random unidirectional behavior in quadrant IV of the polar axis (226-314 ${ }^{\circ}$ clockwise, under the influence of the synodic cycle between the waning gibbous and waning crescent (intermediate albedo): (a) Boana polytaenia, (b) Hylodes phyllodes, (c) Ischnocnema aff. guentheri, (d) Myersiela microps, (e) Ololygon hiemalis, and (f) Proceratophrys boiei.

sented prolonged reproductive behavior (sensu Wells, 1977) from October to February, which, unlike for opportunistic species, is not predominantly influenced by abiotic factors such as rainfall. As observed in P. melanopogon, the forests' canopies did not influence the lunar-mediated behavior of the forest species.

In the second quadrant (46-134 ${ }^{\circ}$, intermediate albedo), all seven species (Table 4, Fig. 4) exhibited prolonged vocal activity (sensu Wells, 1977) from October to February, except $B$. albopunctata which vocalizes year-round. These species were observed vocalizing on the ground (B. pardalis, L. latrans, and $P$. murundu), perched in ruderal vegetation (B.albopunctata, S. similis, and S. fuscomarginatus), or perched in arbustive vegetation ( $S$. squalirostris) from open areas. Boana albopunctata, despite its statistic one-sidedness significance ( $Z$ and $U$ tests), was, among this species group, the more eurytopic species regarding the lunar-mediated behavior, since it was observed vocalizing in all moon phases.

In the third quadrant $\left(135-225^{\circ}\right.$, higher albedo), D. sanborni and B. faber (Table 5, Fig. 5) were the only species considered to be influenced by the moon. Both exhibit prolonged reproduction (sensu Wells, 1977), which allows them to remain active in various phases of the moon. Dendropso- phus sanborni showed a preference for the phase of increasing to higher albedo, whereas $B$. faber, despite its tendency to follow the same pattern, also showed activity from the beginning of darker periods of the lunar phases. In this case, the behavior of egg laying only after the strongest rains (Pederassi, 2019) can prevent the embryos from being submerged (Kluge, 1981) and the nest from being damaged. These advantages could induce opportunistic behavior to the detriment of the lunar phase of preference.

In the fourth quadrant (226-314 ${ }^{\circ}$, intermediate albedo), six species presented behavior influenced by the moon (Table 6, Fig. 6). As a general pattern, these species have a preference for the beginning of the darkest phase of the lunar cycle and have different behaviors of vocalization and habitat occupation. Most are found in forested areas (H. phyllodes, $I$. aff. guentheri, $M$. microps, and $P$. boiei), and only two are found in open areas (B. polytaenia and $O$. hiemalis). Only $M$. microps and $P$. boiei are explosive breeders (sensu Wells, 1977). In this group of species, O. hiemalis, despite its prolonged reproduction (sensu Wells, 1977), showed more vocal activity in the waning gibbous phase (higher albedo of this quadrant), with vocalization activity occurring exclusively during winter nights in water bodies marginal to forested ar- 
eas (Haddad and Pombal, 1987) where active specimens keep little distance from each other. Therefore, the permanence of activity in phases of greater luminosity may favor visual displays (Duellman and Trueb, 1994; Guimarães and Bastos, 2003); however, because the species has restricted distribution and is active during the winter, there are still no studies of this kind. Boana polytaenia, as observed in B. albopunctata which is active in the second quadrant, despite the statistical significance of one-sidedness activity, remains vocally active year-round and presents eurytopic lunar-mediated behavior as well. The highlight is Hylodes phyllodes which, while presenting diurnal vocalization, exhibits unidirectional behavior of $56 \%$ for this phase of the lunar cycle. In this case, specific studies should be implemented to understand such a relationship. With the present data, we can only raise hypotheses such as lunar influence goes beyond the luminous influence as a gravitational or electromagnetic force as proposed by Zimecki (2006), the nocturnal foraging activity of $H$. phyllodes could be favored by the darkest phase to avoid predators (Tuttle and Ryan, 1982; Tuttle et al., 1982) which would ensure more energy for daytime vocalization, or the lunar phase could trigger female ovulation synchronism (Church, 1960a) and the vocalization of males.

Summarizing our results, from the 37 observed species, 12 were mainly vocally active in the darkest phase (315$\left.45^{\circ}\right), 2$ were mainly vocally active in the lighter phase (135$225^{\circ}$ ), and an intermediate number of individuals were vocally active in intermediate light ( 7 between 46 and $134^{\circ}$, 6 between 226 and $314^{\circ}$ ). Although their prevalent activity was in the darkest phase, 2 species were statistically considered random. And, finally, 8 had an insufficient sample. Grant et al. (2012) reported that among 79 species of amphibians, whose behavior was analyzed with regards to the lunar phases, 20 species were positively influenced by the full moon, 30 species were negatively influenced, 17 species were indifferent to the lunar phases, and 12 species had ambiguous behavior. Therefore, the distinct behaviors observed in the current work are consistent with those noted in previous studies (Duellman, 1967; Forester and Lykens, 1986; Rand et al., 1997; Magnusson et al., 1999; Johnson and Batie, 2001; Hauselberger and Alford, 2005; Abrunhosa et al., 2006; Taylor et al., 2007; Granda et al., 2008). The results presented in this study are the first steps to understanding the lunar influence on the anuran species of Mantiqueira.

\section{Conclusions}

Lunar phases influence the vocalization pattern of most anuran species, with the third quarter, new moon, and first quarter - the darker phases - having a higher prevalence of activity, whereas the full moon is the phase with the lowest prevalence of species showing vocalization activity.

In this study, the influence of the lunar cycle was not the same for all species. There is a specific trend for each species, where the natural history of each group should be considered; hence, it is necessary to study these species to understand such relationships.

Data availability. Data used in this study are available at https: //search.dataone.org/view/PPBioAmOc.629.1 (Pederassi, 2020).

Author contributions. MSCSL, JP, and UC designed the experiments. JP carried them out. MSCSL performed the statistics. KDSSS performed the line draws. MSCSL and JP prepared the manuscript with contributions from all co-authors.

Competing interests. The authors declare that they have no conflict of interest.

Acknowledgements. We are grateful to the SISBIO and IBAMA for authorizing the research in the Área de Proteção Ambiental (APA) da Serra da Mantiqueira (no. 50094), the Pró-Fundação Mantiqueira for authorizing the research at the RPPN Fazenda Boa Vista, the managers of RPPN Ave Lavrinha, and farmers and residents in the region for authorizing the research on their properties. We thank Rogério Bastos and the two anonymous referees for their valuable contributions.

Review statement. This paper was edited by Matthias Foellmer and reviewed by Rogério Bastos and two anonymous referees.

\section{References}

Abrunhosa, P. A., Wogel, H., and Pombal-Jr., J. P.: Temporal anuran occupancy in a temporary pond from the Atlantic rain forest southeastern Brazil, Herpetol. J., 16, 115-122, 2006.

Arnfield, H., Grant, R., Monk, C., and Uller, T.: Factors influencing the timing of spring migration in common toads (Bufo bufo), J. Zool., 288, 112-118, https://doi.org/10.1111/j.14697998.2012.00933.x, 2012.

Bastos, R. P., Motta, J. A. O., Lima, L. P., and Guimarães, L. D. A.: Anfíbios da Floresta Nacional da Silvânia, Estado de Goiás, Goiânia: R.P. Bastos, 82 pp., 2003.

Batschelet, E.: Circular statistics in biologym London, New York, Acadmic Press, 371 pp., 1981.

Baugh, A. T. and Ryan, M. J.: Ambient light alters temporalupdating behavior during mate choice in a Neotropical frog, Can. J. Zool., 88, 448-453, 2010.

Bertoluci, J.: Annual patterns of breeding activity in Atlantic rainforest anurans, J. Herpetol., 32, 607-611, 1998.

Bourne, G. R. and York, H.: Vocals behaviors are related to nonrandom structure of anuran breeding assemblages in Guyana, Ethol. Ecol. Evol., 13, 313-329, https://doi.org/10.1080/08927014.2001.9522763, 2001. 
Campbell, S. R., Mackessy, S. P., and Clarke, J. A.: Microhabitat use by brown treesnakes Boiga irregularis; effects of moonlight and prey, J. Herpetol., 42, 246-250, 2008.

Church, G.: Annual and lunar periodicity in the sexual cycle of the Javanese toad Bufo melanostictus Schneider, Zoologica, 45, 181188, 1960a.

Church, G.: The effects of seasonal and lunar changes on the breeding pattern of the edible Javanese frog Rana cancrivora (Gravenhorst), Treubia, 25, 214-233, 1960b.

Church, G.: Seasonal and lunar variation in the numbers of mating toads in Bandung, Java, Herpetology, 17, 122-126, 1961.

Clarke, J. A.: Moonlight's influence on predator/prey interactions between short-eared owls (Asio flammeus) and deermice (Peromyscus maniculatus), Behav. Ecol. Sociobiol., 13, 205-209, 1983.

Costa, J. R. V.: The phases of the Moon - Part 2. Astronomy in Zenith, available at: https://www.zenite.nu/as-fases-da-lua-2 (last access: 22 May 2020), 2000.

Duellman, W. E.: Courtship isolating mechanisms in Costa Rican hylid frogs, Herpetology, 23, 169-183, 1967.

Duellman, W. E. and Trueb, L.: Biology of amphibians, Baltimore, USA, Ed. Johns Hopkins, 670 pp., 1994.

Eterovick, P. C. and Sazima, I.: Anfíbios da Serra do Cipó, Minas Gerais - Brasil Belo Horizonte, PUC Publisher-Minas, 152 pp., 2004.

Farbridge, K. J. and Leatherland, J. F.: Lunar cycles of coho salmon, Oncorhynchus kisutch, J. Exp. Biol., 129, 165-178, 1987.

Forester, D. C. and Lykens, D. V.: Significance of satellite males in a population of spring peepers Hyla crucifer, Copeia, 3, 719-724, https://doi.org/10.2307/1444955, 1986.

Gatto, L. C., Ramos, V. L. S., Nunes, B. T. A., Mamede, L., Goes, M. H. B., Mauro, C. A., Alvarenga, S. M., Franco, E. M. S., Quirico, A. F. et al.: 2 - Geomorfologia. In: Project RADAMBRASIL, Levantamento de Recursos Naturais, edited by Almeida, A. L. S., Moreira, H. F., and Seixas, N. B. Folhas SF.23/24 Rio de Janeiro/Vitória; geologia, geomorfologia, pedologia, vegetação e uso potencial da terra: Rio de Janeiro: MME/SG/RADAMBRASIL Projeto, 301-384 pp., 1983.

Granda, J., Pena, R., and Pierce, B.: Effects of disturbance position of observer and moonlight on efficiency of anuran call surveys, Appl. Herpetol., 5, 253-263, https://doi.org/10.1163/157075408785910995, 2008.

Grant, R. A., Chadwick, E. A., and Halliday, T.: The lunar cycle: A cue for amphibian reproductive phenology?, Anim. Behav., 78, 349-357, https://doi.org/10.1016/j.anbehav.2009.05.007, 2009.

Grant, R. A., Halliday, T., and Chadwick, E. A.: Amphibians' response to the lunar synodic cycle - A review of current knowledge, recommendations and implications for conservation, Behav. Ecol., 24, 53-62, https://doi.org/10.1093/beheco/ars135, 2012.

Guimarães, L. and Bastos, R. P.: Vocalizações e interações acústicas em Hyla raniceps (Anura, Hylidae) durante a atividade reprodutiva, Iheringia, 93, 149-158, https://doi.org/10.1590/S007347212003000200005, 2003.

Haddad, C. F. B. and Pombal-Jr., J. P.: Hyla hiemalis nova espécie do grupo rizibilis do estado de São Paulo (Amphibia, Anura, Hylidae), Rev. Bras. Biol., 47, 127-132, 1987.

Hauselberger, K. F. and Alford, R. A.: Effects of season and weather on calling in the Australian microhylid frogs Austrochaperina robusta and Cophixalus ornatus, Herpetologica, 61, 349-363, https://doi.org/10.1655/04-03.1, 2005.

Henrique, R. S. and Grant, T.: Influence of environmental factors on short-term movements of butter frogs (Leptodactylus latrans), Herpetologica, 75, 38-46, https://doi.org/10.1655/D-1800018.1, 2019.

Heyer, W. R., Rand, A. S., Cruz, C. A. G., Peixoto, O. L., and Nelson, C. E.: Frogs of Boracéia, Arq. Zool., 31, 231-410, 1990.

Hödl, W. and Amézquita, A.: Visual signaling in anuran amphibians, in: Anuran communication, edited by: Ryan, M. J., Washington, DC, Smithsonian Institution Press, 121-141 pp., 2001.

ICMBio, Instituto Chico Mendes de Conservação da Biodiversidade: APA da Serra da Mantiqueira, available at: http://www.icmbio.gov.br/portal/biodiversidade/ unidades-de-conservacao/biomas-brasileiros/mata-atlantica/ unidades-de-conservacao-mata-atlantica/2177, last access: 22 June 2020.

Jammalamadaka, S. R. and SenGupta, A.: Topics in circular statistics, Series on Multivariate Analysis, vol. 5, World Scientific, 336 pp., 2001.

Johnson, D. H. and Batie, R. D.: Surveys of calling amphibians in North Dakota, Prairie Nat., 33, 227-247, 2001.

Kluge, A. G.: The life history, social organization, and parental behavior of Hyla rosenbergi Boulenger, the nest-building gladiator frog, Misc. Pub. Mus. Zool. U. Mich., 160, 1-170, 1981.

Kolence, K. W. and Kiviat, P. J.: Software unit profiles and Kiviat figures, Perf. E. R. SI., 2, 2-12, 1973.

Lima, M. S. C. S. and Pederassi, J.: Introdução à ecologia dos anfíbios anuros. In: Métodos em ecologia e comportamento animal, edited by: Lima, M. S. C. S., Carvalho, L. S., and Prezoto, F., EDUFPI, 187-215, 2015.

Longcore, T. and Rich, C.: Ecological light pollution, Front. Ecol. Environ., 2, 191-198, https://doi.org/10.1890/15409295(2004)002[0191:ELP]2.0.CO;2, 2004.

Magnusson, W. E., Lima, A. P., Hero, J., and Araujo, M. C.: The rise and fall of a population of Hyla boans: Reproduction in a Neotropical gladiator frog, J. Herpetol., 33, 647-656, https://doi.org/10.2307/1565582, 1999.

Margalef, R.: Limnología, Ediciones Omega S/A, Barcelona, 1010 p., 1983.

Neto, S. S.: Manual de ecologia de insetos, Editora Agronômica Ceres, São Paulo, SP, 419 pp., 1976.

Paranjpe, D. A. and Sharma, V. K.: Evolution of temporal order in living organisms, J. Circadiam. Rhythms, 3, 7, https://doi.org/10.1186/1740-3391-3-7, 2005.

Parsons, K. N., Jones, G., and Greenaway, F.: Swarming activity of temperate zone microchiropteran bats: Effects of season, time of night and weather conditions, J. Zool., 261, 257-264, https://doi.org/10.1017/S0952836903004199, 2003.

Pederassi, J.: Riqueza, bioacústica e ecologia dos anfíbios anuros de Bocaina de Minas, MG, [Doctoral thesis]: UFRJ, Museu Nacional, 222 pp., 2019.

Pederassi, J.: Frog vocalization is influenced by moon phases: Brazilian frogs tend to prefer low-albedo phases, Programa de Pesquisa em Biodiversidade (PPBio), PPBioAmOc.629.1, available at: https://search.dataone.org/view/PPBioAmOc.629.1 (last access: 4 January 2021), 2020.

Rand, A. S., Bridarolli, M. E., Dries, L., and Ryan, M. J.: Light levels influence female choice in tungara frogs: Predation risk 
assessment?, Copeia, 447-450, https://doi.org/10.2307/1447770, 1997.

Sazima, I. and Caramaschi, U.: Descrição de Physalaemus deimaticus, sp. n., e observações sobre comportamento deimático em P. nattereri (Steindn.) - Anura, Leptodactylidae, Rev. Biol., 13, 91-101, 1986.

Taylor, R. C., Buchanan, B. W., and Doherty, J. L.: Sexual selection in the squirrel treefrog Hyla squirella: The role of multimodal cue assessment in female choice, Anim. Behav., 74, 1753-1763, https://doi.org/10.1016/j.anbehav.2007.03.010, 2007.

Tuttle, M. D. and Ryan, M. J.: The role of synchronized calling, ambient light and ambient noise in anti-bat predator behavior of a treefrog, Behav. Ecol. Sociobiol., 11, 125-131, https://doi.org/10.1007/BF00300101, 1982.

Tuttle, M. D., Taft, L. K., and Ryan, M. J.: Evasive behavior of a frog in response to bat predation, Anim. Behav., 30, 393-397, https://doi.org/10.1016/S0003-3472(82)80050-X, 1982.
Vignoli, L. and Luiselli, L.: Better in the dark: two Mediterranean amphibians synchronize reproduction with moonlit nights, Web Ecol., 13, 1-11, https://doi.org/10.5194/we-13-1-2013, 2013.

Vincent, S. E., Shine, R., and Brown, G. P.: Does foraging mode influence sensory modalities for prey detection in male and female filesnakes, Acrochordus arafurae?, Anim. Behav., 70, 715-721, https://doi.org/10.1016/j.anbehav.2005.01.002, 2005.

Wells, K. D.: The social behavior of anuran amphibians, Anim. Behav., 25, 666-693, 1977.

Wells, K. D.: The ecology and behavior of amphibians, Chicago, University of Chicago Press, 1162 pp., 2007.

Zimecki, M.: The lunar cycle: effects on human and animal behavior and physiology, Postepy. Hig. Med. Dosw., 60, 1-7, 2006. 